\title{
Adaptive model of DOM dynamics in the surface ocean
}

\author{
by Markus Pahlow ${ }^{1}$ and Alain F. Vézina ${ }^{1}$
}

\begin{abstract}
The bulk of marine dissolved organic matter (DOM) forms a large, old, refractory carbon pool in the deep ocean, yet a small fraction in the surface ocean is actively involved in the global carbon cycle and may contribute significantly to the biological pump. We argue that present models of plankton and DOM in the surface ocean are incompatible with current knowledge of marine DOM dynamics. We present a plankton model with an adaptive formulation of bacteria-DOM interactions which is more consistent with observations. Our model reproduces net accumulation of DOM and is the first to reconcile the prevailing reports of net consumption of inorganic nitrogen by bacteria with commonly found DOC:DON ratios in the surface ocean.

Our model predicts that factors governing DOM production by phytoplankton and zooplankton have little influence on DOM accumulation in the surface ocean. Long-term accumulation, eventual export of DOM, and hence its contribution to the biological pump appear to be primarily controlled by characteristics of bacterial DOM utilization. The model implies a negative relation between temperature and DOM accumulation, which can be obscured, however, by the impact of temperature on water-column stability. On longer time scales, this negative relation could indicate a positive feedback between temperature and $\mathrm{CO}_{2}$. DOM can accumulate independently of inorganic nutrient content of the surface ocean. Therefore, the predicted positive feedback is potentially very strong and could help explain the large variations in atmospheric $\mathrm{CO}_{2}$ between glacial and interglacial periods.
\end{abstract}

\section{Introduction}

Dissolved organic matter (DOM) is by far the largest pool of organic carbon in the ocean, similar to the amount of atmospheric $\mathrm{CO}_{2}$. Its high apparent age of 40006000 years (Druffel et al., 1992) had initially been interpreted as indicating that marine DOM was an inert and hence climatically inactive pool. But the observation of rapid DOM turnover and the recent discovery of high rates of photo-mineralization in the surface ocean (Mopper et al., 1991; Miller and Zepp, 1995; Mopper and Kieber, 2000) prove that marine DOM plays a very active role in the global carbon cycle.

Marine DOM has traditionally been divided into several fractions associated with different turnover times. DOM cycled on time scales of hours-to-days is called labile, time scales of weeks-to-months are typically used for semi-labile DOM (Anderson and Williams, 1999). Most of the DOM comprises a large, refractory pool responsible for the

1. Bedford Institute of Oceanography, P.O. Box 1006, Dartmouth, Nova Scotia, B2Y 4A2, Canada. e-mail: pahlowm@mar.dfo-mpo.gc.ca 
high apparent age of marine DOM. Much of the DOM is originally released in the form of labile material (Keil and Kirchman, 1994; Kepkay, 2000), which is available for bacterial utilization, and photochemical reactions at the sea surface can render significant amounts of refractory DOM labile (Miller and Zepp, 1995; Mopper and Kieber, 2000). Nevertheless, DOM accumulates in the surface ocean on a seasonal time scale and creates a vertical gradient, which causes a net export of DOM to the deep sea (Williams, 1995). Thingstad $e t$ al. (1997) suggested that the seasonal accumulation could be due to a malfunctioning microbial loop, in which strong grazing by zooplankton would prevent bacteria from utilizing all available DOM. Other studies have shown that DOM accumulation could also occur as the result of transformations among different DOM fractions with an efficient microbial loop (e.g., Anderson and Williams, 1999).

DOM export can be similar to or larger than particulate export production in some ocean areas (Anderson and Williams, 1999; Carlson et al., 1994), which makes it a significant part of the biological carbon pump. Inclusion of DOM in biogeochemical models has significantly improved the performance of these models (Anderson and Williams, 1999). However, we argue that present models are not in line with current knowledge of marine DOM dynamics in two major respects. Firstly, bacterial assemblages have been observed to adapt to changing substrate concentrations on a time scale of days (Kirchman et al., 1995), but the Michaelis-Menten type equations used to describe bacterial DOM utilization do not account for this adaptive capability of bacterial assemblages. Secondly, bacteria are normally assumed to regenerate DOM back to $\mathrm{CO}_{2}$ and inorganic nutrients, but they appear to compete for dissolved inorganic nitrogen (DIN) in the surface ocean rather than remineralize DON (Goldman and Dennett, 1991; Jørgensen et al., 1994; Kirchman and Wheeler, 1990; Thingstad et al., 1997). Formulations of DOM dynamics in present models combined with commonly observed DOC:DON ratios make bacteria remineralize DIN in the surface ocean (e.g., Anderson and Williams, 1998; Bissett et al., 1999), contrary to all observations that we are aware of.

The goal of the present study is to examine processes which lead to the build-up of DOM and its eventual export from the surface ocean. We present an adaptive model of surface-marine plankton and DOM dynamics and find that our formulation agrees more closely with current knowledge than those used in previous models. Our model concentrates on biological processes so as to highlight the interaction between plankton communities and marine DOM. This approach allows us to separate effects of biological and physical processes on DOM cycling in the surface ocean.

\section{Adaptive model}

Labile, semi-labile, and refractory DOM fractions are usually modeled as separate state variables. In our model we use a slightly different approach and define lability as the fraction of the total DOM concentration which is available for bacterial utilization. Hence, we view lability as a variable property of one DOM pool. While mathematically equivalent to modeling labile and refractory fractions, using labilities of DOC $\left(\lambda_{C}\right)$ and DON $\left(\lambda_{N}\right)$ as 


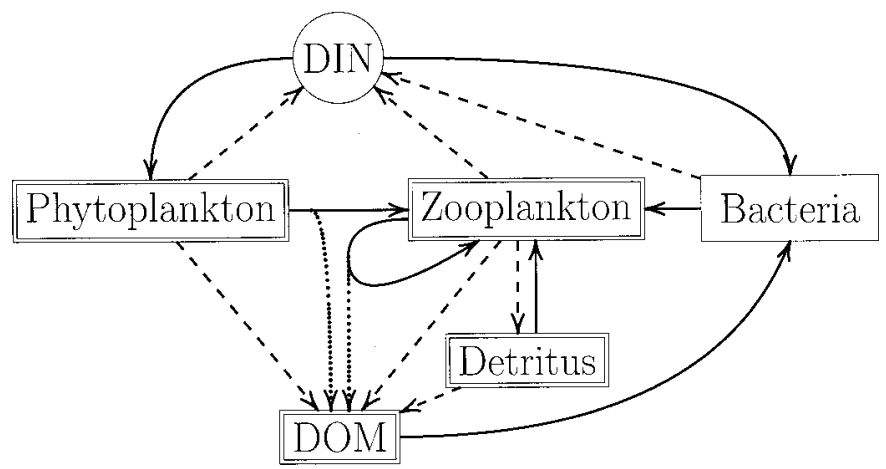

Figure 1. Model diagram with material state variables. Solid lines indicate uptake or grazing, dashed lines indicate excretion or disintegration, and dotted lines represent sloppy-feeding losses. Variables with double boxes are represented by separate $\mathrm{C}$ and $\mathrm{N}$ compartments in the model.

state variables makes the model more transparent and easier to comprehend with respect to processes affecting DOM lability.

Material state variables represent separate carbon and nitrogen compartments for phytoplankton $\left(C_{P}, N_{P}\right)$, zooplankton $\left(C_{Z}, N_{Z}\right)$, detritus $\left(C_{D}, N_{D}\right)$, and DOM $\left(\mathbf{C}_{o}, \mathbf{N}_{o}\right)$, and one compartment each for bacterial biomass $\left(C_{B}\right)$ and DIN $\left(\mathbf{N}_{i}\right)$ as shown in Figure 1. Parameters are summarized in Table 1.

\section{a. Bacterial DOM utilization}

The model is based on the assumption that bacteria compete against each other by adapting to variable substrate, i.e., DOM, concentrations. In order to adapt to changing DOM concentrations, bacteria must be able to sense and utilize such changes, which is impossible if the uptake mechanism is saturated. Bacteria whose DOM uptake saturates will be replaced by others which are capable of utilizing higher DOM concentrations. Therefore, the saturating behaviour of bacterial DOM utilization observed on the small temporal and spatial scales of lab experiments is unlikely to be relevant for bacterial assemblages in the real ocean. In accordance with this view, half-saturation constants for bacterial DOM utilization used in previous models were at least 4 times the maximal modeled labile DOC concentrations (Table 2), i.e., DOM concentrations remained well within the roughly linear part of the Michaelis-Menten function used in these models. Also, bacterial activity reported by Cherrier et al. (1996) did not exhibit saturation at higher DOM concentrations.

Another problem with the Michaelis-Menten formulation is its behaviour at low substrate concentration. Many zooplankton species are known to feed only above a certain threshold food concentration because of the energy these animals must spend for foraging and pursuit of prey. Bacteria also need to spend considerable energy for the production of extracellular enzymes necessary for the utilization of marine DOM. One would therefore 
Table 1. Parameter definitions and settings.

\begin{tabular}{|c|c|}
\hline Parameter & Value \\
\hline$\alpha$ & $1.4 \cdot 10^{-7} \mathrm{~m}^{2} \mu \mathrm{E}^{-1}$ \\
\hline$D_{D}$ & $0.05 \mathrm{~d}^{-1}$ \\
\hline$D_{\Lambda}$ & $0.03 \mathrm{~d}^{-1}$ \\
\hline$E_{B}$ & 0.25 \\
\hline$E_{Z}$ & 0.75 \\
\hline$f_{X}$ & 0.12 \\
\hline$f_{X}^{d}$ & 0.25 \\
\hline$G_{x, \max }$ & $1 \mathrm{~d}^{-1}$ \\
\hline$K_{P}^{N}$ & $0.5 \mu \mathrm{mol} \mathrm{l}^{-1}$ \\
\hline$k_{Q_{P}}$ & $0.04 \mathrm{gN} \mathrm{gC}^{-1}$ \\
\hline$\Lambda_{B}^{\prime}$ & $1 \mathrm{~m}^{3} \mathrm{gC}^{-1}$ \\
\hline$\Lambda_{Z}^{x}$ & $0.5,5 \mathrm{~m}^{3} \mathrm{gC}^{-1}$ \\
\hline$P_{P, \max }$ & $3 d^{-1}$ \\
\hline$Q_{B}$ & $0.2 \mathrm{gN} \mathrm{gC}^{-1}$ \\
\hline$Q_{X}$ & $0.01 \mathrm{gN} \mathrm{gC}^{-1}$ \\
\hline$Q_{s}$ & $0.02 \mathrm{gN} \mathrm{gC}^{-1}$ \\
\hline$R$ & $0.03 \mathrm{~d}^{-1}$ \\
\hline$S_{D}$ & $0.4 \mathrm{~d}^{-1}$ \\
\hline$s_{Z}$ & 0.1 \\
\hline$V_{B}^{\prime}$ & $3 d^{-1}$ \\
\hline$V_{P, \text { max }}^{N}$ & $0.6 \mathrm{gN} \mathrm{gC}^{-1} \mathrm{~d}^{-1}$ \\
\hline
\end{tabular}

Light absorption coefficient (Geider et al., 1998) $)^{\dagger}$

Detritus disintegration rate (Anderson and Williams, 1998)

Abiotic decrease of DOM lability (Keil and Kirchman, 1994)

Bacterial gross growth efficiency (Amon and Benner, 1994)

Zooplankton assimilation efficiency (Fasham et al., 1990)

Ratio of extracellular release to photosynthesis(Baines and Pace, 1991)

Diss. fraction of zooplankton excretion (Olsen et al., 1986)

Maximum ingestion rate by zooplankton(Fasham et al., 1990)

Phytopl. DIN half-saturation constant (Fasham et al., 1990)

Phytoplankton subsistence N quota (Geider et al., 1998)

Ivlev constant for bacterial DOM uptake

Ivlev constants for grazing* (Franks et al., 1986)

Maximum gross photosynthesis(Geider et al., 1998)

$\mathrm{N}: \mathrm{C}$ ratio of bacteria (Anderson and Williams, 1998)

$\mathrm{N}: \mathrm{C}$ ratio of phytoplankton extrac. release $\mathrm{e}^{\mathrm{Il}}$

$\mathrm{N}$ : C ratio of sloppy-feeding loss $\mathrm{s}^{\mathrm{II}}$

Metabolic (respiratory) loss rate (Geider et al., 1998)

Detritus sinking loss rate

Sloppy feeding parameter (Roy et al., 1989)

Bacterial DOM uptake parameter (Bissett et al., 1999)

Maximum phytoplankton C-specific $\mathrm{N}$ uptake rate (Geider et al., 1998)

${ }^{\dagger}$ assuming a C:Chl ratio of 60

${ }^{\ddagger}$ obtained from a fit of Eq. 1 to oxygen utilization data of Cherrier et al. (1996), assuming a refractory DOC:DON ratio of 10

*Franks et al. (1986) use $11(\mu \mathrm{mol} \mathrm{N})^{-1}$, equivalent to about $10 \mathrm{~m}^{3}(\mathrm{gC})^{-1}$, with phytoplankton as the only prey. We use $0.5 \mathrm{~m}^{3} \mathrm{gC}^{-1}$ for $\Lambda_{Z}^{B}, 5 \mathrm{~m}^{3} \mathrm{gC}^{-1}$ for $\Lambda_{Z}^{P}, \Lambda_{Z}^{D}$, and $\Lambda_{Z}^{Z}$. The small $\Lambda_{Z}^{B}$ is dictated by the frequent observation that bacterial biomass is higher, except in blooms, than phytoplankton biomass, despite lower bacterial than primary production (Kirchman et al., 1995)

"see text

\# ratio of sinking rate of $10 \mathrm{~m} \mathrm{~s}^{-1}$ (Fasham et al., 1990) and mixed-layer depth of $25 \mathrm{~m}$

$\S$ estimated from maximum uptake rate

expect bacteria to display some kind of threshold behaviour when utilizing marine DOM. Results from Cherrier et al. (1996) show commencement of bacterial activity only above a threshold DOM concentration. Thus, a linear relation between DOM concentration and uptake, resulting, e.g., from the above-mentioned use of high half-saturation constants, does not appear to correctly represent bacterial DOM utilization. For these reasons, we 
Table 2. Half-saturation constants $\left(K_{M}\right)$ for bacterial DOC or DON utilization and maximal modeled DOC or DON concentrations (DOM) in models of marine DOM dynamics.

$$
K_{M}
$$

$25 \mu \mathrm{M} \mathrm{DOC}^{\dagger}$

$417 \mu \mathrm{M} \mathrm{DOC}^{\ddagger}$

$130 \mu \mathrm{M}$ DOC

$0.5 \mu \mathrm{M}$ DON

${ }^{\dagger}$ labile fraction

${ }^{\ddagger}$ semi-labile fraction
DOM

$<5 \mu \mathrm{M} \mathrm{DOC}^{\dagger}$
$60 \mu \mathrm{M} \mathrm{DOC}^{\ddagger}$
$<6 \mu \mathrm{M} \mathrm{DOC}^{\dagger}$
$0.01 \mu \mathrm{M} \mathrm{DON}$

Ref.

Anderson and Williams (1998, 1999) Anderson and Williams $(1998,1999)$ Bissett et al. (1999)

Fasham et al. (1990)

replace the Michaelis-Menten formula with the Mayzaud-Poulet formula whose shallow slope at low substrate concentrations mimics a threshold behaviour and whose constant slope at higher concentrations (Mayzaud and Poulet, 1978; Franks et al., 1986) allows for the adaptive capability of bacteria (Kirchman et al., 1995):

$$
V_{B}^{\text {DOM }}=C_{B} V_{B}^{\prime} \Lambda_{B}^{\prime} \lambda_{C} \mathbf{C}_{o}\left(1-e^{-\Lambda \dot{k}^{\prime} \lambda C_{o}}\right)
$$

where $\mathbf{C}_{o}$ is the DOC concentration, $V_{B}^{\mathrm{DOM}}$ is the actual rate of DOM uptake by bacteria and $V_{B}^{\prime}$ is the slope of the relationship between $V_{B}^{\mathrm{DOM}}$ and labile DOC concentration $\left(\lambda_{C} \mathbf{C}_{o}\right.$ ) at high $\lambda_{C} \mathbf{C}_{o}$ (Fig. 2). $\Lambda_{B}^{\prime}$ is the bacterial Ivlev constant (Franks et al., 1986), which determines the behavior of Eq. 1 at low $\lambda_{C} \mathbf{C}_{o}$ and can be estimated from observed thresholds. The two main assumptions behind the Mayzaud-Poulet formulation, i.e., adaptation to changing substrate concentration and a threshold, are met only for time scales longer than a day. Thus, the Mayzaud-Poulet formula does not describe the short-term response to extremely strong and rapid changes in substrate concentration. Eq. 1 could be extended to include a saturating short-term response by replacing $V_{B}^{\prime} \Lambda_{B}^{\prime} \lambda_{C} \mathbf{C}_{o}$ with a new state variable as suggested by Franks et al. (1986).

Bacterial respiration $\left(R_{B}\right)$ is the fraction $\left(1-E_{B}\right)$ of $V_{B}^{\text {DOM }}$, where $E_{B}$ is bacterial gross growth efficiency. We introduce an apparent DON:DOC ratio $Q_{\mathrm{DOM}}^{\prime}$, which is the ratio in which DON and DOC are utilized in bacterial DOM uptake, i.e., the ratio of labile DON and labile DOC:

$$
Q_{\mathrm{DOM}}^{\prime}=\frac{\lambda_{N} \mathbf{N}_{o}}{\lambda_{C} \mathbf{C}_{o}}
$$

We follow previous models in distinguishing three cases with respect to the relative utilization of DOC, DON, and DIN by bacteria as determined by $Q_{\mathrm{DOM}}^{\prime}$ and $R_{B}$ (e.g., Anderson and Williams, 1998). In the first case DON and DIN cannot deliver enough nitrogen for bacteria to utilize all available DOC. Excess DOC is respired:

$$
V_{B}^{N}=C_{B} V_{B}^{\prime} Q_{B} \frac{\mathbf{N}_{i}}{\mathbf{N}_{i}+K_{B}^{N}}
$$




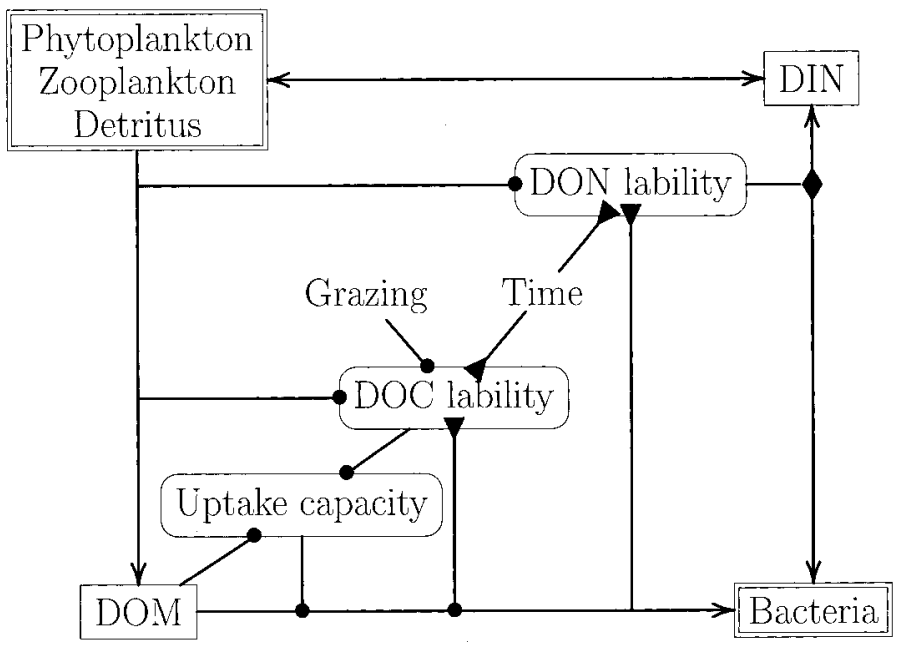

Figure 2. Regulation of DOM and DIN uptake and remineralization by bacteria. Arrows indicate material fluxes, round tips indicate positive, triangles negative influence, the lozenge represents an influence on the direction of the flow. DOM utilization is governed by DOM concentration, lability, and bacterial uptake capacity, which in turn adapts to DOM concentration and lability. DOM lability increases by addition of fresh (labile) DOM and decreases over time and as a result of specific bacterial utilization of labile DOM. DOC lability also increases by adsorption of DFAA released during sloppy feeding (grazing). DON lability mainly determines whether DIN is utilized or remineralized by bacteria.

$$
R_{B}=V_{B}^{\mathrm{DOM}}\left(1-\frac{Q_{\mathrm{DOM}}^{\prime}}{Q_{B}}\right)-\frac{V_{B}^{N}}{Q_{B}}
$$

where $V_{B}^{N}, Q_{B}$, and $K_{B}^{N}$ are bacterial DIN uptake, N:C ratio, and DIN half saturation constant, respectively. In the other two cases total $\mathrm{N}$ supply satisfies bacterial $\mathrm{N}$ demand. We assume that DON is preferentially utilized and augmented by DIN uptake only if required:

$$
\begin{gathered}
V_{B}^{N}=V_{B}^{\mathrm{DOM}}\left(E_{B} Q_{B}-Q_{\mathrm{DOM}}^{\prime}\right) \\
R_{B}=V_{B}^{\mathrm{DOM}}\left(1-E_{B}\right)
\end{gathered}
$$

The second case (Eq. 3b, positive $V_{B}^{N}$ ) is given if DIN must be utilized in addition to DON to supply enough $\mathrm{N}$, while bacteria remineralize inorganic nitrogen in the third case (Eq. 3 b, negative $V_{B}^{N}$ ).

\section{b. DOM lability}

The model includes three major processes affecting DOM lability. Firstly, all fresh DOM is initially released in labile form, i.e., $\lambda_{C}=1$ and $\lambda_{N}=1$ for all fluxes into the DOM pool. The resulting rates of change are 


$$
\left(\frac{d \lambda_{C}}{d t}\right)_{f}=\frac{d \mathbf{C}_{o}}{d t} \frac{1-\lambda_{C}}{\mathbf{C}_{o}} \quad\left(\frac{d \lambda_{N}}{d t}\right)_{f}=\frac{d \mathbf{N}_{o}}{d t} \frac{1-\lambda_{N}}{\mathbf{N}_{o}},
$$

where $d \mathbf{C}_{o} / d t$ and $d \mathbf{N}_{o} / d t$ are the net DOC and DON rates of change. Secondly, DOM lability decreases over time following a first-order decay function with decay constant $D_{\lambda}$, giving rates of change of $-D_{\lambda} \lambda_{C}$ and $-D_{\lambda} \lambda_{N}$. This decay simulates the abiotic decline of DOM lability in the presence of daylight demonstrated by Keil and Kirchman (1994). Photochemical processes not only render labile DOM refractory, but also transform refractory DOM into labile DOM and mineralize DOM directly to $\mathrm{CO}_{2}$ (Moran and Zepp, 1997; Mopper and Kieber, 2000). Although photo-mineralization removes large amounts of refractory DOM from the surface ocean, the main impact on our model would be via addition and removal of labile DOM, because we did not include import of refractory DOM. Since the balance of photochemical transformations with respect to labile DOM is not known, we could not account for photochemical reactions of refractory DOM in our model. Omission of this process should not be too problematic, however, because phototransformation of refractory DOM probably supplies only a relatively small fraction of the total labile DOM for bacterial utilization (<5\%, Moran and Zepp, 1997).

The third effect is an increase in DOC lability by adsorption of dissolved free amino acids (DFAA) to refractory DOC as reported by Schuster et al. (1998) and Mari (1999). The effect is modeled as a selective increase in DOC lability $\lambda_{C}$ by the release of fresh DON in DFAA as determined by current DOC lability and DOC:DON ratio. This change in $\lambda_{C}$ is in addition to that caused by adding the labile DOC contained in the DFAA. We consider sloppy feeding (see below) the most important source of DFAA. Thus, $\lambda_{C}$ will change at a rate

$$
\left(\frac{d \lambda_{C}}{d t}\right)_{s}=s^{C} Q_{s} \frac{\mathbf{C}_{o}}{\mathbf{N}_{o}} \frac{1-\lambda_{C}}{\mathbf{C}_{o}},
$$

where $s^{C}$ and $Q_{s}$ are the sloppy-feeding loss and its DOC:DON ratio, respectively.

The equations for $\lambda_{C}$ and $\lambda_{N}$ are then given by

$$
\begin{gathered}
\frac{d \lambda_{C}}{d t}=\left(\frac{d \lambda_{C}}{d t}\right)_{f}+\left(\frac{d \lambda_{C}}{d t}\right)_{s}-D_{\lambda} \lambda_{C} \\
\frac{d \lambda_{N}}{d t}=\left(\frac{d \lambda_{N}}{d t}\right)_{f}-D_{\lambda} \lambda_{N}
\end{gathered}
$$

\section{c. Phytoplankton}

Photosynthesis $\left(P_{P}\right)$ and nutrient uptake $\left(V_{P}^{N}\right)$ are given by the model of Geider et al. (1998), assuming a constant $\mathrm{C}: \mathrm{Chl}$ a ratio and exclusive light or nutrient limitation of photosynthesis. Extracellular release of DOC and DON by phytoplankton $\left(X_{P}^{C}\right.$ and $X_{P}^{N}=$ $Q_{X} X_{P}^{C}$, where $Q_{X}$ is the N:C ratio of extracellular release) can vary considerably (Baines 
and Pace, 1991), but the general behavior has been shown to be most appropriately described by a constant fraction $f_{X}$ of photosynthesis (Baines and Pace, 1991): $X_{P}^{C}=f_{X} P_{P}$. Nitrogen compounds constitute between 1.5 and $10 \%$ of $X_{P}^{C}$ (Myklestad, 2000). With a molar N:C ratio of 0.2 for $\mathrm{N}$ compounds, $Q_{X}$ should lie between 0.003 and 0.023 . Respiration at rate $R$ directly converts $C_{P}$ and $N_{P}$ to DIC and $\mathbf{N}_{i}$.

\section{d. Zooplankton and detritus}

Zooplankton grazing on phytoplankton $\left(G_{P}^{C}\right)$, bacteria $\left(G_{B}^{C}\right)$, detritus $\left(G_{D}^{C}\right)$, and zooplankton $\left(G_{Z}^{C}\right)$ is formulated as the modified Mayzaud-Poulet mechanism given by Franks et al. (1986). Instead of using additional state variables for different size classes of micro-, meso-, and macro-zooplankton, we treat effects of higher trophic levels by having zooplankton feed on itself (Fig. 1):

$$
G_{Z}^{C}=C_{Z} G_{Z, m} \Lambda_{Z}^{Z} C_{Z}\left(1-e^{-\Lambda_{Z}^{Z} C^{Z}}\right),
$$

where $G_{Z, m}$ is referred to as the maximum ingestion rate (Franks et al., 1986), although it is actually a rate constant relating grazing to food concentration, and $\Lambda_{Z}^{Z}$ is the Ivlev constant for self grazing. Self grazing is qualitatively different from a simple mortality term because of its relation to sloppy feeding and detritus production. Grazing on other prey is obtained by replacing $\Lambda_{Z}^{Z} C_{Z}$ with the prey state variable and the corresponding Ivlev constant. Multiplying the right-hand side of Eq. 9 with the prey $\mathrm{N}: \mathrm{C}$ ratio gives the $\mathrm{N}$ intake from grazing.

DOC and DON are released by zooplankton through active excretion $\left(X_{Z}^{C}\right.$ and $\left.X_{Z}^{N}\right)$ and as sloppy-feeding losses $\left(s^{C}\right.$ for DOC and $Q_{s}{ }^{C}$ for DON, $Q_{s}$ is the N:C ratio of sloppy-feeding losses). Sloppy feeding is assumed to result only from eating large prey (Roy et al., 1989), i.e., phytoplankton and zooplankton:

$$
s^{C}=s_{Z}\left(G_{P}^{C}+G_{Z}^{C}\right),
$$

where $s_{Z}$ is the fraction of caught phytoplankton and zooplankton lost by sloppy feeding. Soluble material from ruptured cells contains ca. 10\% N compounds (Myklestad, 2000) with a $\mathrm{N}: \mathrm{C}$ ratio of ca. 0.2 , giving $Q_{s}=0.02$. Zooplankton digest ingested material (grazing less sloppy feeding) with assimilation efficiency $E_{Z}$ and excrete the rest:

$$
\begin{gathered}
X_{Z}^{C}=\left(1-E_{Z}\right)\left(G_{P}^{C}+G_{B}^{C}+G_{D}^{C}+G_{Z}^{C}-s_{C}\right) \\
X_{Z}^{N}=\left(1-E_{Z}\right)\left(G_{P}^{N}+Q_{B} G_{B}^{C}+G_{D}^{N}+G_{Z}^{N}-Q_{s} s_{C}\right)
\end{gathered}
$$

A fraction $f_{X}^{d}$ of zooplankton excretion is released as DOM. The remainder is egested as fecal pellets and ends up as detritus. Zooplankton respiration (at rate $R$ ) remineralizes $N_{Z}$ back to $\mathbf{N}_{i}$ (Fasham et al., 1990). Detritus disintegrates with rate $D_{D}$, which is another source of DOM. C and $\mathrm{N}$ in sinking detritus are lost from the model domain. Detritus sinking losses are given by the rate constant $S_{D}$, which is the ratio of sinking velocity and height of the model domain. 


\section{e. Model equations and setup}

The above processes have been integrated with the help of Eqs. 7, 8, and the following set of differential equations:

$$
\begin{gathered}
\frac{d C_{B}}{d t}=V_{B}^{\mathrm{DOM}}-R_{B}-G_{B}^{C} \\
\frac{d \mathbf{C}_{o}}{d t}=X_{P}^{C}+f_{X}^{d} X_{Z}^{C}+s^{C}+D_{D} C_{D}-V_{B}^{\mathrm{DOM}} \\
\frac{d \mathbf{N}_{o}}{d t}=X_{P}^{N}+f_{X}^{d} X_{Z}^{N}+Q_{s} s^{C}+D_{D} N_{D}-V_{B}^{\mathrm{DOM}} Q_{\mathrm{DOM}}^{\prime} \\
\frac{d \mathbf{N}_{i}}{d t}=R N_{P}+R N_{Z}-V_{P}^{N}-V_{B}^{N} \\
\frac{d C_{P}}{d t}=P_{P}-R C_{P}-X_{P}^{C}-G_{P}^{C} \\
\frac{d N_{P}}{d t}=V_{P}^{N}-R N_{P}-X_{P}^{N}-G_{P}^{N} \\
\frac{d C_{Z}}{d t}=G_{P}^{C}+G_{B}^{C}+G_{D}^{C}-s^{C}-X_{Z}^{C}-R C_{Z} \\
\frac{d N_{Z}}{d t}=G_{P}^{N}+Q_{B} G_{B}^{C}+G_{D}^{N}-Q_{s} s^{C}-X_{Z}^{N}-R N_{Z} \\
\frac{d C_{D}}{d t}=X_{Z}^{C}\left(1-f_{X}^{d}\right)-D_{D} C_{D}-G_{D}^{C}-S_{D} C_{D} \\
\frac{d t}{d}=D_{D} N_{D}-G_{D}^{N}-S_{D} N_{D}
\end{gathered}
$$

The model is used to examine the build-up of DOM in the upper mixed layer. We will therefore focus mainly on the model output regarding DOM concentration and accumulation and DOC:DON ratios. In order to make the results less dependent on initial values of state variables, we define a model cycle of 90 days after which the DIN concentration is restored to the initial value. Restoring DIN concentration is meant to mimic mixing events which introduce new nutrients into the surface layer. The model cycle is then repeated until all the remaining state variables return to approximately the same values after each cycle. 

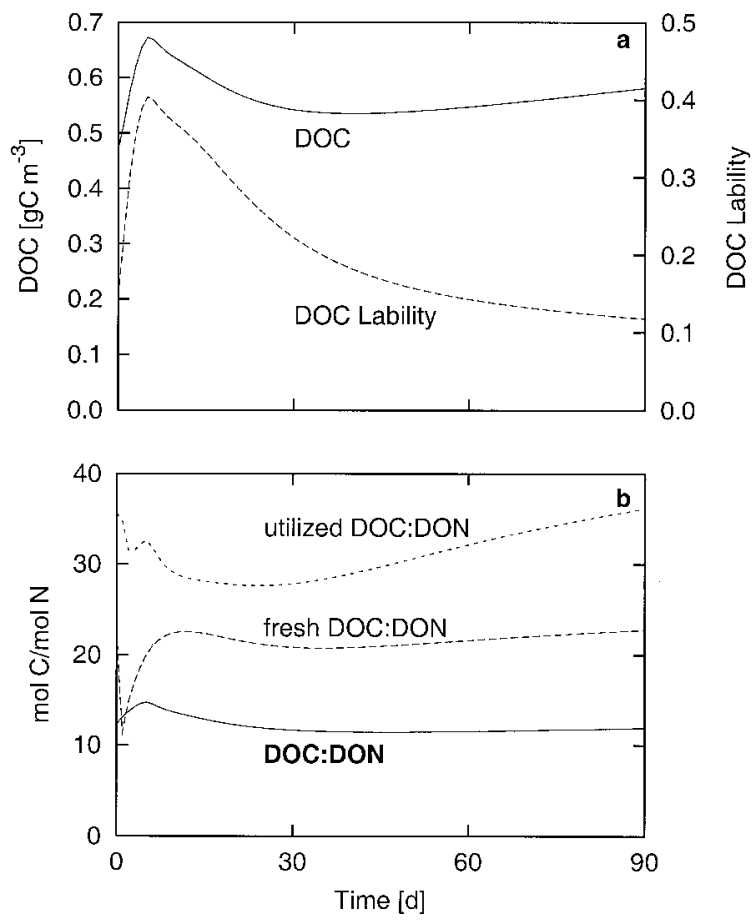

Figure 3. a. DOC $\left(\mathbf{C}_{o}\right)$ and DOC lability $\left(\lambda_{C}\right)$ during a model cycle. b. Comparison of the C:N ratio of total DOM (solid curve) with that of freshly-released DOM (dashed curve) and the utilized DOC:DON ratio (dotted curve). The model was run over $25 \mathrm{~m}$ depth with a 12:12 light-dark cycle and $1000 \mu \mathrm{E} \mathrm{m}^{-2} \mathrm{~s}^{-1}$ noon-time surface irradiance. DOC and DON were initially set to 0.1 and $0.01 \mathrm{~g} \mathrm{~m}^{-3}$, respectively, and to be labile $\left(\lambda_{C}=\lambda_{N}=1\right)$.

\section{Results}

\section{a. Simulation of a bloom event}

The model cycle mimics a phytoplanktonbloom after convective nutrient import and the subsequent period of regenerated production. The bloom lasts roughly two weeks. DOC concentration temporarily increases by ca. $15 \mu \mathrm{mol}^{-1}$ (Fig. 3a) and peaks during the first half of the bloom, due to the release of fresh DOM, mostly from phytoplankton. Because the fresh DOM is labile, lability peaks at the same time as DOC concentration, enabling bacteria to utilize most of the newly added DOM during the second half of the bloom. Removal of labile DOM and the abiotic decline in lability cause DOC concentration and lability to diverge after the bloom, however, leading to a slow long-term accumulation of DOC within the model domain.

The length of the model cycle is not critical for the DOM accumulation: DOM continues to rise during extended model cycles without DIN additions for several hundred days, although the DON increase weakens after about 6 months. A longer model cycle mainly 
raises the C:N ratio of the accumulating DOM. Resetting DIN to higher concentrations at the start of a model cycle has essentially the same effect on DOM accumulation and DOC:DON ratio as shortening the model cycle.

The addition of fresh DOM during the bloom also temporarily increases the DOC:DON ratio (Fig. 3b, solid curve). Much more revealing is the behaviour of two other DOC:DON ratios readily obtained from the model results: the ratios in which DOC and DON are released by the plankton community (fresh DOC:DON) and consumed by bacteria (utilized DOC:DON). Because fresh DOM is labile, one would expect a certain similarity in the development of fresh and utilized DOC:DON ratios. To the contrary, these two DOC:DON ratios bear no resemblance at all at the time of the most intense release of DOM during the bloom, and only a weak covariance after the end of the bloom (Fig. 3b). The differential development of fresh and labile DOC:DON ratios is also evident in the consistently higher values of the utilized $(\approx 30)$ as compared to the fresh DOC:DON ratio $(\approx 22)$. With a growth efficiency $E_{B}$ of $0.25, Q_{B}=0.2$, and $Q_{\mathrm{DOM}}^{\prime}=1 / 30$, bacteria can obtain a fraction $Q_{\text {DOM }}^{\prime}\left(E_{B} Q_{B}\right)=0.67$ of their $\mathrm{N}$ demand from DON, i.e., about one third must be satisfied by DIN uptake.

\section{b. Sensitivity analysis}

The sensitivity analysis was performed by varying each model parameter from one half to twice the value given in Table 1 and examining the effect on two simulation results: the overall DOC:DON ratio (Fig. 3b, solid line) and the DOC accumulation rate averaged over one model cycle $A_{\mathrm{DOM}}$. Changes of more than $20 \%$ in $A_{\mathrm{DOM}}$ and DOC:DON are shown in Figure 4. The sensitivity analysis reveals two major lines of the model's response to parameter variations. The first (Fig. 4, solid line) is characterized by rather strong changes in both DOM accumulation rate and DOC:DON ratio, the second (Fig. 4, dashed lines) also shows strong reactions of DOC:DON, but in this case accompanied by only relatively minor changes in $A_{\mathrm{DOM}}$. Both lines of response show that strong changes in $A_{\mathrm{DOM}}$ can only occur simultaneously with strong changes in DOC:DON ratio, while the DOC:DON ratio can vary without an appreciable variation in $A_{\mathrm{DOM}}$ along the second response line.

The two response lines are associated with two separate groups of model parameters. The first line mainly represents effects of parameters determining DOM lability and bacterial DOM utilization (Eqs. 1-8), the second line delineates reactions to changes in zooplankton activity (Eqs. 9-12). Interestingly, effects of phytoplankton parameters are much weaker than those shown in Fig. 4, although phytoplankton are the main source of DOM during the simulation.

Our assumption that all new DOM is released in a labile form is probably not entirely realistic. If, rather than being initially labile, a small fraction of fresh DOM was inherently refractory, the resulting increase in DOM accumulation rate would be accompanied by an increase in DOC:DON ratio, owing to the higher DOC:DON ratio of fresh as compared to total DOM (Fig. 3b). This reaction would correspond to changes along the first response line mentioned above. Thus, aside from enhanced DOM accumulation, we would not 


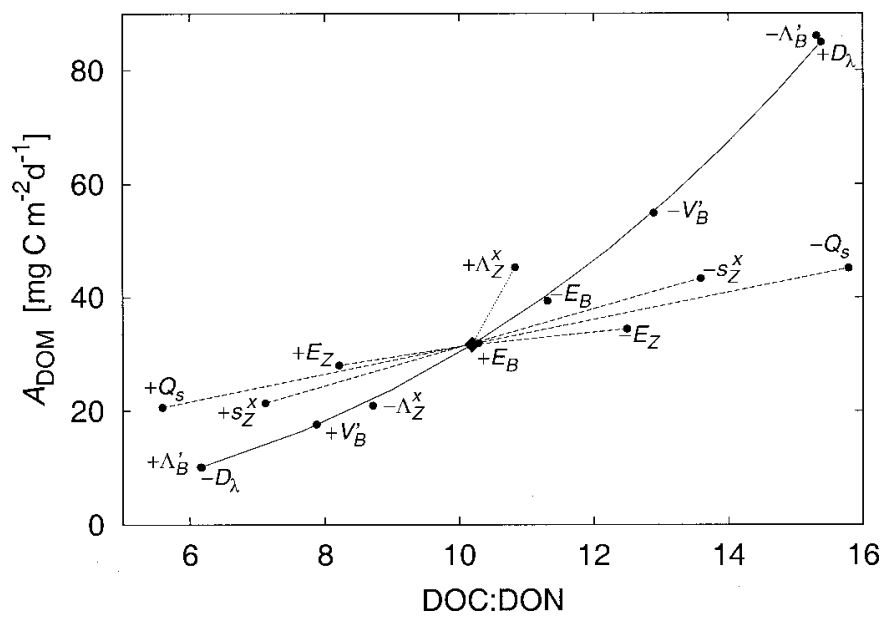

Figure 4. Sensitivity of net DOM accumulation rate $\left(d \mathbf{C}_{o} / d t\right)$ and its DOC:DON ratio in response to variations of model parameters. The $\bullet$ indicates parameter settings from Table $1 .+$ and indicate doubling or halving of the indicated parameters with respect to their values given in Table 1 , except $E_{Z}$, whose range was $0.5-0.875$. For example, the point labeled $-V_{B}^{\prime}$ marks the result from running the model with $V_{B}^{\prime}=1.5 \mathrm{~d}^{-1}$.

expect a significant change in model behaviour, in particular with respect to the link between DOC accumulation and DOC:DON ratio.

\section{Discussion}

\section{a. Nutrient competition and remineralization}

All DOM in our simulation originates within the model domain as no DOM is ever imported or exported. Thus, the modeled DOM must be compared to excess DOM which accumulated in the surface ocean over background DOM concentrations, taken here to be those found in deeper waters. The correspondence of the accumulating DOM to the semi-labile and refractory fractions differs according to the region under consideration. Semi-labile and refractory fractions are usually defined with respect to DOM oceanic residence time, with times of months to years associated with semi-labile and centuries to millennia associated with refractory. In regions of deep-water formation, part of the accumulating DOM will be added to the deep, refractory pool, while it should be considered semi-labile where a permanent pycnocline prevents export to the deep ocean.

Bulk DOC:DON ratios in our model vary well within values typically found for excess DOM in the surface ocean (Fig. 5). In addition, the modeled fresh DOC:DON ratio (Fig. $3 \mathrm{~b}$, dashed line) is very close to the ratio of accumulating fresh DOC and DON in the North Atlantic reported by Kähler and Koeve (2001). Studies on the properties of labile and refractory DOM show that the DOC:DON ratio of labile DOM is often much higher than that of refractory DOM (10-30 vs. 5-10, respectively; Amon and Benner, 1994; Kepkay et 


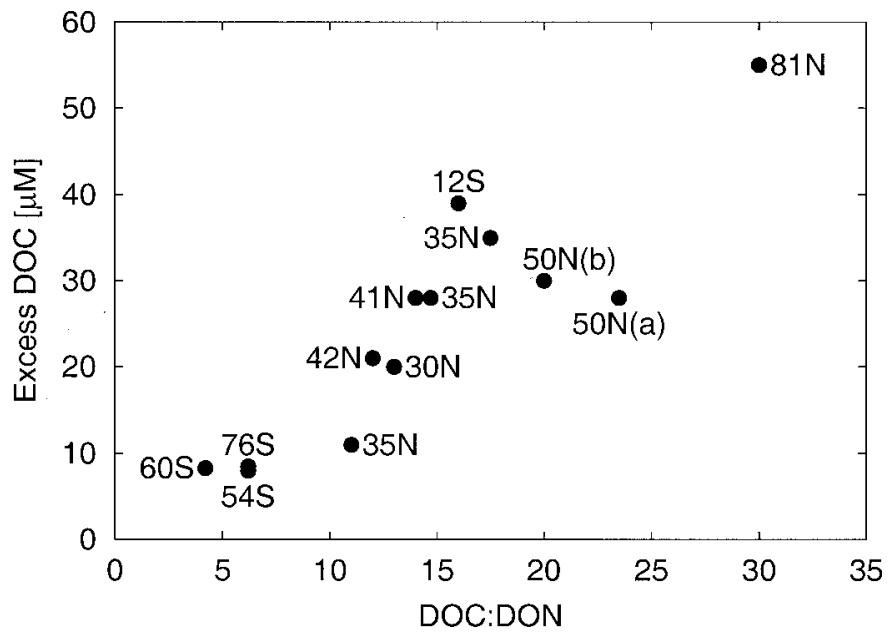

Figure 5. Excess DOC concentration versus DOC:DON ratio from the literature. Labels indicate approximate latitude and refer to references as follows. 12S: Benner et al. (1997) using data from Clark et al. (1998); 76S: Carlson et al. (2000); 81N: Daly et al. (1999) assuming deep-water DON and DOC concentrations of 5 and $50 \mu \mathrm{M}$, respectively; 42N: Doval et al. (1997); 41N: Hopkinson et al. (1997); 50N(a): Kähler and Koeve (2001); 54S and 35N: Loh and Bauer (2000); 60S: Ogawa et al. (1999); 30N: Williams et al. (1980); 50N(b): Williams (1995) using data from Banoub and Williams (1973) for mid-summer increase. Data from Carlson et al. (2000) and Kähler and Koeve (2001) are for accumulating DOM.

al., 1997; Kähler and Koeve, 2001). Hence, a separation of DOC:DON ratios must occur somewhere during the process of transformation of fresh, labile DOM to the refractory material forming the bulk of marine DOM.

The separation and partial decoupling of several DOC:DON ratios in our model leads to a rather high DOC:DON ratio of DOM utilized by bacteria. Thus, while bacteria satisfy their $\mathrm{N}$ demand predominantly by DON utilization, they also compete with phytoplankton for DIN in our model domain. While bacteria are generally assumed to be responsible for the remineralization of most marine DOM, competition for DIN between bacteria and phytoplankton is commonly observed in the surface ocean (e.g., Kirchman and Wheeler, 1990; Goldman and Dennett, 1991; Jørgensen et al., 1994; Thingstad et al., 1997). This argument does not deny that bacteria can remineralize DON, but it does restrict the role of bacteria as DON remineralizers to below the photic zone. The models of Anderson and Williams (1998) and Bissett et al. (1999), for example, contain a similar regulation of DON and DIN uptake and remineralization as that employed here (Eqs. 3a-4b), i.e., they would have bacteria utilize DIN if the DOC:DON ratio was high enough. Owing to the lack of a mechanism allowing the utilized DOC:DON ratio to depart significantly from the bulk DOC:DON ratio, however, bacteria always remineralize DON in these models.

Our mechanism for separating DOC:DON ratios critically depends on the ability of bacteria to adapt to and utilize the additional DOC made available by adsorption of DFAA. 
If saturation of bacterial DOM uptake prevented increased utilization, the additional DOC would simply accumulate until it would eventually become refractory again. Whether adsorption of DFAA released by sloppy feeding is indeed the main process rendering otherwise inaccessible DOC labile requires further research. For example, addition of DIN has also been shown to facilitate DOM utilization (Amon and Benner, 1994). Nevertheless, we consider the separation of DOC:DON ratios a major improvement over previous models, because it reconciles prevailing DOC:DON ratios with the role of bacteria as competitors for DIN in marine plankton communities, and at the same time explains differences in DOC:DON ratios between labile and refractory DOM.

\section{b. DOC:DON ratios}

The sensitivity analysis showed that pronounced changes in DOC accumulation are tightly linked to corresponding changes in DOC:DON ratio. Such a strong covariation between $A_{\mathrm{DOM}}$ and DOC:DON ratio suggests that most of the variation along the first response line of the model is due to changes in $A_{\mathrm{DOM}}$ with relatively little variability in DON accumulation.Conversely, variability along the second line of response (little change in $A_{\mathrm{DOM}}$, variable DOC:DON ratio) is predominantly due to changes in DON accumulation. Altogether, it follows that variations in DOC and DON accumulation can occur largely independent of each other and are associated with different sets of parameters in our model (Fig. 4).

In order to assess the decoupling of DOC and DON accumulation predicted by the model, we collected data on excess (above deep-water) DOC concentration and DOC: DON ratios from the literature (Fig. 5). We find the same link between DOC accumulation and DOC:DON ratio as revealed by the sensitivity analysis, albeit with some scatter and over a wider range of values. Thus, the decoupling of DOC and DON accumulation predicted by our model appears to be a crucial feature of large-scale patterns of excess DOM in the surface ocean. Uncoupled DOC and DON accumulation is probably also typical for the smaller scale of individual study sites, however, as reported by Williams (1995), Daly et al. (1999), Ogawa et al. (1999), and Körtzinger et al. (2001). A recent study by Hansell and Carlson (2001) indicates that the link between DOC:DON ratio and DOC accumulation could be valid for temporal variations: the lowest $\mathrm{C}: \mathrm{N}$ ratios in Bermuda Atlantic time-series data coincided with the lowest concentrations of total organic carbon (which was mostly DOC in that study).

\section{c. Bacterial control of DOM accumulation}

Large variations in DOC accumulation without corresponding changes in DON are characteristic of the first line of the model's response shown in the sensitivity analysis. This line of response is associated mostly with parameters governing bacterial consumption of DOM (Fig. 4, solid line). Although phytoplankton is the main source of DOM in our model simulation, variation of phytoplankton parameters produces no appreciable effect on DOM accumulation. Zooplankton parameters influence most strongly the DOC:DON ratio and 
have less impact on DOM accumulation than bacterial parameters. Bacterial control of marine DOM contradicts the concept of a malfunctioning microbial loop by Thingstad $e t$ al. (1997), according to which bacterial activity is limited by strong grazing pressure and insufficient nutrient supply. Hence, bacteria could not utilize all available DOM, and DOM accumulation would be largely controlled by DOM production instead of consumption. Conversely, grazing pressure on bacteria is relatively weak (Table 1) in our model, allowing bacteria to form the largest plankton compartment in terms of biomass after the bloom. Nutrients also did not limit bacterial growth as supply from DIN and DON was always sufficient for fully assimilating all DOM taken up. DOM accumulates in our model as a consequence of chemical DOM transformations (Keil and Kirchman, 1994) strongly amplified by selective removal of labile DOM by bacteria.

An advantage of our model is that it explains DOM accumulation as a general phenomenon throughout the surface ocean (Fig. 5), while the malfunctioning microbial loop would largely restrict DOM accumulation to more nutrient rich environments (Thingstad et al., 1997). Furthermore, the predicted bacterial regulation of DOM accumulation is in line with findings that bacteria-mediated transformation of DOM can control the accumulation of refractory DOM in the surface ocean (Brophy and Carlson, 1989; Amon et al., 2001; Ogawa et al., 2001).

\section{d. Regional pattern of DOM accumulation}

Bacterial regulation of DOM accumulation implies a negative relationship between temperature and DOM concentration. Bacterial respiration is strongly tied to DOM utilization (Cajal-Medrano and Maske, 1999), such that the strong influence of temperature on DOM uptake (Bissett et al., 1999) translates only into a weak effect on growth rates (Rivkin et al., 1996). The result is an inverse relationship between $V_{B}^{\mathrm{DOM}}$ and bacterial growth efficiency $E_{B}$ (Rivkin and Legendre, 2001). One must be careful in evaluating the temperature-DOM relationship because of the many inter-correlations of temperature with other factors, such as mixing regime, nutrients, etc., which in turn can affect DOM accumulation. For example, warm regions with a permanent pycnocline could develop much larger DOM gradients with time than cold sites of deep-water formation, where the DOM gradient is eradicated annually. Increased stratification may thus contribute to the positive relationship between temperature and DOM reported for some low-latitude regions (Hansell and Waterhouse, 1997; Hansell and Feely, 2000; Hansell and Carlson, 2001).

Figure 5 shows that both the largest and the weakest vertical DOC gradients occur in high latitude regions, with intermediate gradients at mid and low latitudes. Much of the contrast between southern and northern high latitudes is probably due to processes not included in our model. But some of the differences between these regions correspond to variations in model parameters. For example, the Southern Ocean measurements are characterized by deep convection and iron limitation, and the point at $81 \mathrm{~N}$ is from the Northeast Water Polynya (NEW). The high DOM concentrations in the NEW are typical 
for Arctic regions and have been attributed to riverine influx (Daly et al., 1999). The negative effect of temperature on DOM predicted by our model could also contribute to the difference between this and warmer regions. Another important factor could be that ice cover during much of the year prevents photochemical DOM removal, which is a significant DOM sink in other regions (Kepkay, 2000; Mopper and Kieber, 2000).

The low Antarctic DOM concentrations may be related to the particular plankton structure in the Southern Ocean. Southern Ocean plankton communities are dominated by large phytoplankton cells (Priddle et al., 1995; Sweeney et al., 2000) and lacks the strong picophytoplankton presence (Carlson et al., 1998) typical for many other regions (DuRand et al., 2001). Therefore, most organic matter is exported in particulate form as fecal pellets and sinking phytoplankton (Carlson et al., 2000). Although the model cannot directly simulate changes in community structure, we can approximate some of these characteristics of Southern-Ocean plankton by changes in corresponding model parameters. While it seems logical to assume that iron limitation of phytoplankton could hinder the production of DOM, the model does not respond strongly to changes in phytoplankton parameters. Much more impact is exerted by the parameters for fecal pellet production $\left(f_{X}^{d}\right)$ and detritus sinking $\left(S_{D}\right)$, which could be changed to represent the greater importance of fecal pellet export. Larger plankton organisms and high DIN concentrations also imply a larger contribution of sloppy feeding (parameter $s_{Z}$ ) to DON production, because sloppy feeding is a function of prey size (Roy et al., 1989). These parameter changes all tend to reduce DOC accumulation (Fig. 4), and the sloppy-feeding mechanism brings this scenario in line with the rather labile nature of Antarctic DOM (Carlson et al., 2000; Ogawa et al., 1999). In this way the model can be used to identify links between community structure and DOM accumulation, and, combined with the strong convective activity destroying vertical DOC gradients rapidly in the Southern Ocean, to explain the low DOM concentrations in southern as compared to northern high latitudes.

\section{e. Climate implications}

The negative relation between temperature and DOM implies a positive feedback between temperature and $\mathrm{CO}_{2}$. We have seen above how regional patterns do not always show this relationship between temperature and DOM, as they are determined by factors like stratification and plankton composition, which themselves depend more or less on temperature. Hansell and Carlson (2001) reported a positive relation between temperature and DOM for time-series data in the Sargasso Sea. However, the main determinant of DOM accumulation was the depth of the mixed layer, especially during the winter (Hansell and Carlson, 2001). Further, the low DOM concentrations reported for the low temperatures in that study were due to the erosion of the vertical DOM gradient above the permanent pycnocline by winter mixing, i.e., the temperature-DOM relationship reflects a seasonal signal. The interdependence of temperature and the physical mixing regime on a seasonal time scale would therefore have obscured any direct effect of temperature on DOM accumulation. 
DOM accumulation at low latitudes does not appear to contribute significantly to DOM export to the deep ocean. Hence, the negative relation between temperature and DOM would be most important with regard to a positive feedback between temperature and $\mathrm{CO}_{2}$ on long time scales and in high-latitude regions of deep-water formation, in particular the North Atlantic. The North Atlantic is, among the few regions of significant deep DOM export, the primary location where DOM enters the deep ocean (Hansell and Carlson, 1998). It is also the ocean region which has experienced the strongest temperature variations in glacial-interglacial transitions (Yin and Battisti, 2001).

The uncoupling of DOC and DON suggests that DOC accumulation and export can vary independently of changes in surface-oceanic nutrient content. Together with the large size of the deep-oceanic DOM pool, this indicates a potentially very strong climatic feedback mechanism between temperature and $\mathrm{CO}_{2}$. We assume a change in $V_{B}^{\prime}$ by $50 \%$ to illustrate the possible extent of this mechanism. Such a change in bacterial activity could easily result from temperature changes typical for glacial-interglacial differences (Petit et al., 1999; Sherry et al., 1999). Fig. 4 shows that a reduction in $V_{B}^{\prime}$ roughly corresponds to a proportional increase in DOC accumulation rate. With a total DOC export of ca. 1.4 Gt C year ${ }^{-1}$ (Hansell, 2002), the difference in atmospheric $\mathrm{CO}_{2}$ content between glacials and interglacials would be removed within a couple of hundred years. This is, of course, a very simplistic calculation, as temperature effects on other model parameters would partially offset the reduction in $V_{B}^{\prime}$, to say nothing about different ocean circulation patterns, but it shows how strong the effect could be. We have assumed here that temperature does not significantly influence photochemistry (Anderson and Williams, 1999) and neglected potential variations in ice-cover, which shields DOM from photomineralization at the ocean surface. Inclusion of either effect could only further strengthen the positive feedback, however.

Acknowledgments. We thank R. B. Rivkin for helpful discussions on the topic, W. L. Miller for pointing out some recent literature, and P. E. Kepkay and T. Platt for useful ideas and much help revising an earlier version of the manuscript. The manuscript benefited from the input of three anonymous referees. This work was funded by the Department of Fisheries and Oceans Canada.

\section{REFERENCES}

Amon, R. M. W. and R. Benner. 1994. Rapid cycling of high-molecular-weight dissolved organic matter in the ocean. Nature, 369, 549-552.

Amon, R. M. W., H.-P. Fitznar and R. Benner. 2001. Linkages among the bioreactivity, chemical composition, and diagenetic state of marine dissolved organic matter. Limnol. Oceanogr., 46, 287-297.

Anderson, T. R. and P. J. le B. Williams. 1998. Modelling the seasonal cycle of dissolved organic carbon at Station $E_{1}$ in the English Channel. Estuar. Coast. Shelf Sci., 46, 93-109.

-1999. A one-dimensional model of dissolved organic carbon cycling in the water column incorporating combined biological-photochemical decomposition. Global Biogeochem. Cycles, 13, 337-349.

Baines, S. B. and M. L. Pace. 1991. The production of dissolved organic matter by phytoplanktonand its importance to bacteria: Patterns across marine and freshwater systems. Limnol. Oceanogr., 36, $1078-1090$. 
Banoub, M. W. and P. J. le B. Williams. 1973. Seasonal changes in the organic forms of carbon, nitrogen and phosphorus in sea water at $E_{1}$ in the English Channel during 1968. J. Mar. Biol. Assoc. U. K., 53, 695-703.

Benner, R., B. Biddanda, B. Black and M. McCarthy. 1997. Abundance, size distribution, and stable carbon and nitrogen isotopic compositions of marine organic matter isolated by tangential-flow ultrafiltration. Mar. Chem., 57, 243-263.

Bissett, W. P., J. J. Walsh, D. A. Dieterle and K. L. Carder. 1999. Carbon cycling in the upper waters of the Sargasso Sea: I. Numerical simulation of differential carbon and nitrogen fluxes. Deep-Sea Res. I, 46, 205-269.

Brophy, J. E. and D. J. Carlson. 1989. Production of biologically refractory dissolved organic carbon by natural seawater microbial populations. Deep-Sea Res., 36, 497-507.

Cajal-Medrano, R. and H. Maske. 1999. Growth efficiency, growth rate and the remineralization of organic substrate by bacterioplankton-revisiting the Pirt model. Aquat. Microb. Ecol., 19, 119-128.

Carlson, C. A., H. W. Ducklow, D. A. Hansell and W. O. Smith, Jr. 1998. Organic carbon partitioning during spring phytoplankton blooms in the Ross Sea polynya and the Sargasso Sea. Limnol. Oceanogr., 43, 375-386.

Carlson, C. A., H. W. Ducklow and A. F. Michaels. 1994. Annual flux of dissolved organic carbon from the euphotic zone in the northwestern Sargasso Sea. Nature, 371, 405-408.

Carlson, C. A., D. A. Hansell, E. T. Peltzer and W. O. Smith, Jr. 2000. Stocks and dynamics of dissolved and particulate organic matter in the southern Ross Sea, Antarctica. Deep-Sea Res. II, 47, 3201-3225.

Cherrier, J., J. E. Bauer, and E. R. M. Druffel. 1996. Utilization and turnover of labile dissolved organic matter by bacterial heterotrophs in eastern North Pacific surface waters. Mar. Ecol. Prog. Ser., 139, 267-179.

Clark, L. L., E. D. Ingall and R. Benner. 1998. Marine phosphorus is selectively remineralized. Nature, 393, 426.

Daly, K. L., D. W. R. Wallace, W. O. Smith, Jr., A. Skoog, R. Lara, M. Gosselin, E. Falck, and P. L. Yager. 1999. Non-Redfield carbon and nitrogen cycling in the Arctic: Effects of ecosystem structure and dynamics. J. Geophys. Res., 104, 3185-3199.

Doval, M. D., X. A. Álvarez-Salgado and F. F. Pérez. 1997. Dissolved organic matter in a temperate embayment affected by coastal upwelling. Mar. Ecol. Prog. Ser., 157, 21-37.

Druffel, E. R. M., P. M. Williams, J. E. Bauer and J. E. Ertel. 1992. Cycling of dissolved and particulate organic matter in the open ocean. J. Geophys. Res., 97, 15,639-15,659.

DuRand, M. D., R. J. Olson and S. W. Chisholm. 2001. Phytoplankton population dynamics at the Bermuda Atlantic Time-series station in the Sargasso Sea. Deep-Sea Res. II, 48, 1983-2003.

Fasham, M. J. R., H. W. Ducklow and S. M. McKelvie. 1990. A nitrogen-based model of plankton dynamics in the oceanic mixed layer. J. Mar. Res., 48, 591-639.

Franks, P. J. S., J. S. Wroblewski and G. R. Flierl. 1986. Behavior of a simple plankton model with food-level acclimation by herbivores. Mar. Biol., 91, 121-129.

Geider, R., H. L. MacIntyre and T. M. Kana. 1998. A dynamic regulatory model of phytoplankton acclimation to light, nutrients, and temperature. Limnol. Oceanogr., 43, 679-694.

Goldman, J. C. and M. R. Dennett. 1991. Ammonium regeneration and carbon utilization by marine bacteria grown on mixed substrates. Mar. Biol., 109, 369-378.

Hansell, D. A. 2002. DOC in the global carbon cycle, in Biogeochemistry of Marine Dissolved Organic Matter, D. A. Hansell and C. A. Carlson, eds., Academic, London, 685-715.

Hansell, D. A. and C. A. Carlson. 1998. Net community production of dissolved organic carbon. Global Biogeochem. Cycles, 12, 443-453. 
2001. Biogeochemistry of total organic carbon and nitrogen in the Sargasso Sea: control by convective overturn. Deep-Sea Res. II, 48, 1649-1667.

Hansell, D. A. and R. A. Feely. 2000. Atmospheric intertropical convergence impacts surface ocean carbon and nitrogen biogeochemistry in the western tropical Pacific. Geophys. Res. Lett., 27, 1013-1016.

Hansell, D. A. and T. Y. Waterhouse. 1997. Controls on the distributions of organic carbon and nitrogen in the eastern Pacific Ocean. Deep-Sea Res. I, 44, 843-857.

Hopkinson, Jr., C. S., B. Fry and A. L. Nolin. 1997. Stoichiometry of dissolved organic matter dynamics on the continental shelf of the northeastern U.S.A. Cont. Shelf Res., 17, 473-489.

Jørgensen, N. O. G., N. Kroer and R. B. Coffin. 1994. Utilization of dissolved nitrogen by heterotrophic bacterioplankton: Effect of substrate $\mathrm{C} / \mathrm{N}$ ratio. Appl. Environ. Microbiol., 60, 4124-4133.

Kähler, P. and W. Koeve. 2001. Marine dissolved organic matter: can its C:N ratio explain carbon overconsumption? Deep-Sea Res. I, 48, 49-62.

Keil, R. G. and D. L. Kirchman. 1994. Abiotic transformation of labile protein to refractory protein in sea water. Mar. Chem., 45, 187-196.

Kepkay, P. E. 2000. Colloids and the ocean carbon cycle, in Marine Chemistry, P. J. Wangersky, ed., Springer, Berlin, 35-56.

Kepkay, P. E., S. E. H. Niven and J. F. Jellett. 1997. Colloidal organic carbon and phytoplankton speciation during a coastal bloom. J. Plankton Res., 19, 369-389.

Kirchman, D. L., J. H. Rich and R. T. Barber. 1995. Biomass and biomass production of heterotrophic bacteria along $140^{\circ} \mathrm{W}$ in the equatorial Pacific: Effect of temperature on the microbial loop. Deep-Sea Res. II, 42, 603-619.

Kirchman, D. L. and P. A. Wheeler. 1990. Carbon limitation of ammonium uptake by heterotrophic bacteria in the subarctic Pacific. Limnol. Oceanogr., 35, 1258-1266.

Körtzinger, A., W. Koeve, P. Kähler, and L. Mintrop. 2001. C:N ratios in the mixed layer during the productive season in the northeast Atlantic. Deep-Sea Res. I, 48, 661-688.

Loh, A. N. and J. E. Bauer. 2000. Distribution, partitioning and fluxes of dissolved and particulate organic C, N and P in the eastern North Pacific and Southern Oceans. Deep-Sea Res. I, 47, 2287-2316.

Mari, X. 1999. Carbon content and C:N ratio of transparent exopolymeric particles (TEP) produced by bubbling exudates of diatoms. Mar. Ecol. Prog. Ser., 183, 59-71.

Mayzaud, P. and S. A. Poulet. 1978. The importance of the time factor in the response of zooplankton to varying concentrations of naturally occurring particulate matter. Limnol. Oceanogr., 23, 1144-1154.

Miller, W. L. and R. G. Zepp. 1995. Photochemical production of dissolved inorganic carbon from terrestrial organic matter: Significance to the oceanic organic carbon cycle. Geophys. Res. Lett., 22, 417-420.

Mopper, K. and D. J. Kieber. 2000. Marine photochemistry and its impact on carbon cycling, in The Effects of UV Radiation in the Marine Environment, S. de Mora, S. Demers, and M. Vernet, eds., Cambridge, 101-129.

Mopper, K., X. Zhou, R. J. Kieber, D. J. Kieber, R. J. Sikorski and R. D. Jones. 1991. Photochemical degradation of dissolved organic carbon and its impact on the oceanic carbon cycle. Nature, 353, 60-62.

Moran, M. A. and R. G. Zepp. 1997. Role of photoreactions in the formation of biologically labile compounds from dissolved organic matter. Limnol. Oceanogr., 42, 1307-1316.

Myklestad, S. M. 2000. Dissolved organic carbon from phytoplankton, in Marine Chemistry, P. J. Wangersky, ed., Springer, Berlin, 111-148. 
Ogawa, H., Y. Amagai, I. Koike, K. Kaiser and R. Benner. 2001. Production of refractory dissolved organic matter by bacteria. Science, 292, 917-920.

Ogawa, H., R. Fukuda and I. Koike. 1999. Vertical distributions of dissolved organic carbon and nitrogen in the Southern Ocean. Deep-Sea Res. I, 46, 1809-1826.

Olsen, Y., K. M. Varum and A. Jensen. 1986. Some characteristics of the carbon compounds released by Daphnia. J. Plankton Res., 8, 505-517.

Petit, J. R., J. Jouzel, D. Raynaud, N. I. Barkov, J.-M. Barnola, I. Basile, M. Bender, J. Chappellaz, M. Davis, G. Delaygue, M. Delmotte, V. M. Kotlyakov, M. Legrand, V. Y. Lipenkov, C. Lorius, L. Pépin, C. Ritz, E. Saltzman and M. Stievenard. 1999. Climate and atmospheric history of the past 420,000 years from the Vostok ice core, Antarctica. Nature, 399, 429-436.

Priddle, J., R. Leakey, C. Symon, M. Whitehouse, D. Robins, G. Cripps, E. Murphy and N. Owens. 1995. Nutrient cycling by Antarctic marine microbial plankton. Mar. Ecol. Prog. Ser., 116, 181-198.

Rivkin, R. B., M. R. Anderson and C. Lajzerowicz. 1996. Microbial processes in cold oceans. I. Relationship between temperature and bacterial growth rate. Aquat. Microb. Ecol., 10, 243-254.

Rivkin, R. B. and L. Legendre. 2001. Biogenic carbon cycling in the upper ocean: effects of microbial respiration. Science, 291, 2398-2400.

Roy, S., R. P. Harris and S. A. Poulet. 1989. Inefficient feeding by Calanus helgolandicus and Temora longicornis on Coscinodiscus wailesii: quantitative estimation using chlorophyll-type pigments and effects on dissolved free amino acids. Mar. Ecol. Prog. Ser., 52, 145-153.

Schuster, S., J. M. Arrieta, and G. J. Herndl. 1998. Adsorption of dissolved free amino acids on colloidal DOM enhances colloidal DOM utilization but reduces amino acid uptake by orders of magnitude in marine bacterioplankton. Mar. Ecol. Prog. Ser., 166, 99-108.

Sherry, N. D., P. W. Boyd, K. Sugimoto, and P. J. Harrison. 1999. Seasonal and spatial patterns of heterotrophic bacterial production, respiration, and biomass in the subarctic NE Pacific. Deep-Sea Res. II, 46, 2557-2578.

Sweeney, C., D. A. Hansell, C. A. Carlson, L. A. Codispoti, L. I. Gordon, J. Marra, F. J. Millero, W. O. Smith and T. Takahashi. 2000. Biogeochemical regimes, net community production and carbon export in the Ross Sea, Antarctica. Deep-Sea Res. II, 47, 3369-3394.

Thingstad, T. F., Å. Hagström and F. Rassoulzadegan. 1997. Accumulation of degradable DOC in surface waters: Is it caused by a malfunctioning microbial loop? Limnol. Oceanogr., 42, 398-404.

Williams, P. J. le B. 1995. Evidence for the seasonal accumulation of carbon-rich dissolved organic material, its scale in comparison with changes in particulate material, and the consequentialeffect on net $\mathrm{C} / \mathrm{N}$ assimilation ratios. Mar. Chem., 51, 17-29.

Williams, P. M., A. F. Carlucci and R. Olsen. 1980. A deep profile of some biologically important properties in the central North Pacific Gyre. Oceanol. Acta, 3, 471-476.

Yin, J. H. and D. S. Battisti. 2001. The importance of tropical sea surface temperature patterns in simulations of Last Glacial Maximum climate. J. Clim., 14, 565-581.

Received: 2 July, 2001; revised: 2 February, 2003. 